\title{
Spawning Behavior, Egg Development, Larvae and Juvenile Morphology of Hyphessobrycon eques (Pisces: Characidae) Characidae Fishes
}

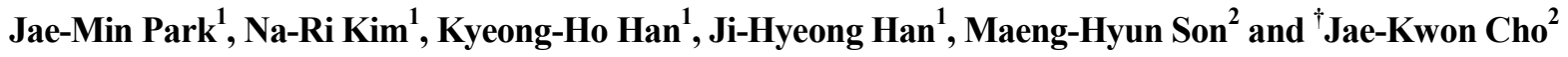 \\ ${ }^{1}$ Dept. of Aqualife Science, Chonnam National University, Yeosu 550-749, Korea \\ ${ }^{2}$ Southwest Sea Fisheries Research Institute, National Fisheries Research and Development Institute, \\ Aquaculture Industry Division, NFRDI, Yeosu 556-823, Korea
}

\begin{abstract}
Hyphessobrycon eques is a famous fish for ornamental fish market and aquarium. They are inhabit in regions of Amazon and Paraguay River basin. Serpae fishs were investigated 2-3 males are chased to female, and then males attempted to simulate the females abdomen. After fertilization, eggs were kept in incubators at $28^{\circ} \mathrm{C}$. The fertilized eggs had adhesive and demesal characteristics and had a mean diameter of $0.92 \pm 0.01 \mathrm{~mm}$. Larvae hatched at 16 hrs post fertilization. The hatched larvae averaged $2.90 \pm 0.16 \mathrm{~mm}$ in total length $\left(L_{T}\right)$. Complete yolk sac resorption and mouth opening occurred on the third day post hatching. At 45 days post hatching, the larvae were $12.5 \pm 1.60 \mathrm{~mm} L_{T}$ and had reached the juvenile stage.

Key words : Egg development, Hyphessobrycon eques, Juvenile, Larvae, Spawning behavior
\end{abstract}

\section{INTRODUCTION}

Hyphessobrycon eques is a teleost belongs to the Characiformes order and Characidae family. These fishes are distributed over the Amazon basin and the Paraguay River basin ranging to Guapore in Brazil and Argentina (Tavares, 1997).

Fishes belong to the Characiformes order are similar to shapes of Cyprinidae family and they have teeth in their buccal cavity. However Cyprinidae family fishes are characterized with pharyngeal teeth and adipose fins (Kim et al., 1996). The shape of the body is small and flat compressed form while there are black spots on top of the pectoral fin near the shoulder, the dorsal fin, and the end of the anal fin. Their body color is bright green or red and female fishes are bigger and have abdominal inflation than male.

Globally, there are several major freshwater aquarium fishes including the Characidae family, the Callichthyidae family, the Cichlidae family, and the Cyprinidae family; in past, these fishes were produced via mostly natural gathering (Lee, 2012), while internal trade as well as natural gathering of aquarium fishes were strictly prohibited as international agencies make issues of protection of endangered species, influx of exotic species, reckless overfishing as well as the spread of diseases, leading many countries to farm these aquarium fishes for their own production (Kim \& Jung, 2011; Kim \& Kang, 2012).

\footnotetext{
Manuscript received 29 October 2014, Received in revised form 18 November 2014, Accepted 20 November 2014

${ }^{\dagger}$ Corresponding Author: Jae Kwon Cho, Southwest Sea Fisheries Research Institute, National Fisheries Research and Development Institute, Aquaculture Industry Division, NFRDI, Yeosu 556-823 Korea. Tel. : +82-61-690-8968, Fax : +82-61-685-9073, E-mail : gost016803@naver.com

This is an Open Access article distributed under the terms of the Creative Commons Attribution Non-Commercial License (http:// creativecommons.org/licenses/by-nc/3.0) which permits unrestricted non-commercial use, distribution, and reproduction in any medium, provided the original work is properly cited.
} 
In South Korea, there are approximately 50-60 aquarium fishes are being produced and commercially distributed; of them, Hyphessobrycon eques is situated as an important group of modern aquarium fishery industry owing to 1) various body colors, 2) small size allowing them to fit in small fish tanks, and 3) ease in breeding (Cole \& Haring, 1999).

There are several domestic studies regarding fine structures of embryos membranes of Hemigrammus ocellifer, Gymnocorymbus ternetzi, H. caudovittatus (Kim et al., 1996) and $H$. serpae (Kim et al., 2005a) whereas anti-oxidative capacity against ammonia stress (Pan et al., 2011), early development of the skull (Vandewalle et al., 2005), and embryonic development (Weber et al., 2012; Nakaghi et al., 2013) of Characidae were reported in international studies.

However, there are not enough investigations have been done regarding the reproduction of commercially available aquarium fishes thus warrants additional investigations as well as acquisition of technologies. Thus, in the present study, we investigated spawning behaviors, egg development, and morphological development of larvae of Hyphessobrycon eques in order to provide basic data for breeding and species conservation of the Characidae family.

\section{MATERIALS AND METHODS}

\section{Breeding conditions}

Matured female/male fishes $(n=30)$ were purchased from the market in July 2011, and then moved into a squared glass fish tank $(50 \times 50 \times 30 \mathrm{~cm})$ in order to observe spawning behaviors. Breeding water was diluted with NO nitrates $(50 \mathrm{~g})$ to eliminate any harmful substances and then $\mathrm{pH}$ was being maintained in between 6.00-6.50 (average 6.25 \pm 0.25 ). The dissolved oxygen concentration was in between $5.94-7.10 \mathrm{mg} / \mathrm{L}$ (average $6.73 \pm 0.29 \mathrm{mg} / \mathrm{L}$ ) and the breeding temperature was maintained in $27.5-28.5^{\circ} \mathrm{C}$ using an automatic water temperature regulator (Warmton 50w). Ex- cretions and remnants accumulated on the bottom of the tank was maintained utilizing the recirculation device (SF2822, Korea). Fishes were fed with blood warms (Hikari, Japan) and assorted feed (Love larva, Japan) twice per day.

\section{Egg development process}

Fertilized eggs were maintained in a $500 \mathrm{~mL}$ beaker and a half of water was changed three times per day. Eggs sizes were measured up to $0.01 \mathrm{~mm}$ utilizing an allpurpose projector (Nikon JP V-12B, Japan) while the process of egg development was observed and photographed using a digital microscope (DIMIS-100, Korea).

\section{Morphological development of larvae (breeding and observations)}

Newly hatched larvae were bred in a squared glass fish tank $(50 \times 50 \times 30 \mathrm{~cm})$ two to three larvae per were maintained and bred in the pond culture system and oxygen was provided via aeration. Larvae were fed with rotifers (Branchionus rotundiformis; 5-10 rotifers per $\mathrm{mL}$ ) over 15 days from the egg yolk absorption and then, replaced with brine shrimps (Artemia Sp. nauplius; Westwood premium gold 10-15 brine shrimps per $\mathrm{mL}$ ) for 15-35 days.

Lastly, from Day 30, assorted feed was provided (200 $310 \mu \mathrm{m}$; Love larva, Japan). Morphological development processes of larvae were monitored once hatched, 10 larvae were retrieved everyday and then anesthetized with tricaine methane sulfonate (MS-222: Sandoz, USA). The larvae were monitored and measured up to $0.01 \mathrm{~mm}$ utilizing the all purpose projector (Nikon JP V-12B, Japan) and a digital camera.

The morphological development stages were classified as described in Rusell (1976).

\section{RESULTS}

\section{Spawning behavior}


Spawning Behavior, Egg Development, Larvae and Juvenile Morphology of Hyphessobrycon eques (Pisces: Characidae) Characidae Fishes

Spawning behaviors of Hyphessobrycon eques were found in which the water temperature was reaching at $27^{\circ} \mathrm{C}$ or higher. Male fishes were thinner and smaller in size compared to female fishes during the spawning period. On the other hand, female fishes had inflated abdomen and opaque ventral fins and anal fins were changed to red color. Compared to female fishes, male anal fins were shorter and sharp at the end female fishes had longer anal fins. Mostly, spawning was done in the morning and classified into early stage, spawning stage, and post-spawning stage.

In the early-stage, male fishes were chasing female and stimulated lower abdomen there of (Fig. 1A) these behaviors were repeated for several times and generally two to three male fishes were going after one female fish (Fig. 1B).

At this moment, the body color of both female/male fishes was changed to dark green. In the spawning stage, a female fish spawned and then adjacent male fish released sperms to fertilize (Fig. 1C).

The spawning was done over two to three seconds and such behaviors were repeated for five to six times. In the post-spawning stage, female and male fishes went after each other repeatedly and their body color was changed back to bright green from dark color (Fig. 1D).

Table 1. Egg and embryonic development Hyphessobrycon eques reared at a mean temperature of $28^{\circ} \mathrm{C}$

\begin{tabular}{|c|c|c|c|}
\hline Stage & Elapsed time & Characters & Fig. 2. \\
\hline \multicolumn{4}{|l|}{ Zygote period } \\
\hline Fertilization & $0 \mathrm{hr} 00 \mathrm{~min}$ & & \\
\hline \multicolumn{4}{|l|}{ Cell cleave period } \\
\hline 32 cell & $2 \mathrm{hr} 00 \mathrm{~min}$ & $4-8$ array of blastomeres & A \\
\hline 64 cell & $2 \mathrm{hr} 30 \mathrm{~min}$ & $8-8$ array of blastomeres & $\mathrm{B}$ \\
\hline \multicolumn{4}{|l|}{ Blastula period } \\
\hline Morula & $3 \mathrm{hr} 00 \mathrm{~min}$ & $\begin{array}{l}\text { The number of blastomeres were increased and this size became } \\
\text { smaller, blastomeres were overlapped. }\end{array}$ & $\mathrm{C}$ \\
\hline Blastula & $3 \mathrm{hr} 30 \mathrm{~min}$ & Marginal cell was expanded slopingly to vegetal pole. & $\mathrm{D}$ \\
\hline \multicolumn{4}{|l|}{ Gastrula period } \\
\hline Gastrulation & $4 \mathrm{hr} 00 \mathrm{~min}$ & Blastula came down and cover the yolk. & $\mathrm{E}$ \\
\hline \multicolumn{4}{|l|}{ Embryoric period } \\
\hline & $5 \mathrm{hr} 00 \mathrm{~min}$ & Blastopore closure & $\mathrm{F}$ \\
\hline & $6 \mathrm{hr} 30 \mathrm{~min}$ & Head development & \\
\hline & $7 \mathrm{hr} 00 \mathrm{~min}$ & Formation of optic vesicles and Kupffer's vesicles & G \\
\hline & $8 \mathrm{hr} 30 \mathrm{~min}$ & $\begin{array}{l}13-17 \text { myotomes, formation of auditory vesicles, disappear Kupffer's } \\
\text { vesicles }\end{array}$ & $\mathrm{H}$ \\
\hline & $11 \mathrm{hr} 00 \mathrm{~min}$ & 20-25 myotomes, tale seperated & I \\
\hline & $11 \mathrm{hr} 30 \mathrm{~min}$ & 26-28 myotomes, Formation of primordial finfold & $\mathrm{J}$ \\
\hline \multirow[t]{3}{*}{$\begin{array}{l}\text { Beginning of heart } \\
\text { beating }\end{array}$} & $13 \mathrm{hr} 30 \mathrm{~min}$ & $\begin{array}{l}30-32 \text { myotomes, Heartbeat has begin, tale become sharpen and } \\
\text { longer }\end{array}$ & $\mathrm{K}$ \\
\hline & $14 \mathrm{hr} 30 \mathrm{~min}$ & 35-38 myotomes, Motion observed, Blood flow observed & $\mathrm{L}$ \\
\hline & $15 \mathrm{hr} 00 \mathrm{~min}$ & 70-75 myotomes & M \\
\hline Hatching & $16 \mathrm{hr} 00 \mathrm{~min}$ & Haching is beginning; Head headonapical part of egg membrane & $\mathrm{N}$ \\
\hline
\end{tabular}


A
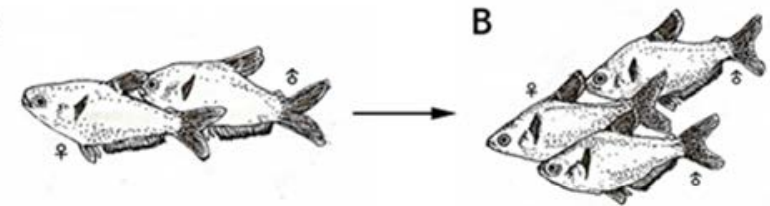

D

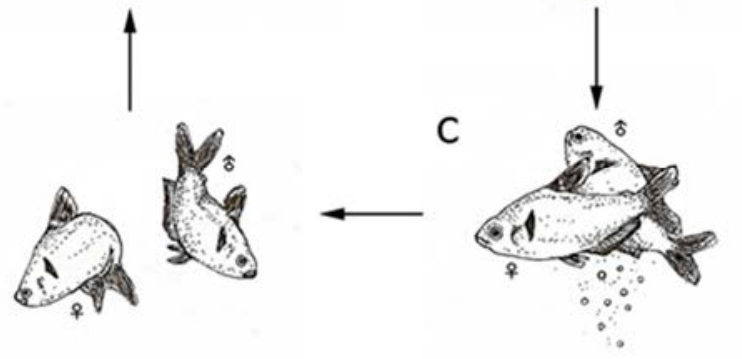

Fig. 1. Spawning behavior of Hyphessobrycon eques. (A) Courtship and follow; (B) Simulate the male of female; (C) Spawning; (D) Release.

\section{Egg morphology}

When it comes to the morphology of eggs, there was no lipid droplets found and the egg yolk was red colored. Fertilized eggs were found to be sticky demersal egg and the diameter of eggs were ranging between $0.91-0.93 \mathrm{~mm}$ (mean $0.92 \pm 0.01 \mathrm{~mm}, n=10$ ).

\section{Egg development processes}

Two $\mathrm{hr}$ after the fertilization, eggs were in the 32 cell stage (Fig. 2A) and then became to the 64 cell stage after 2 hour and 30 min later (Fig. 2B) after $3 \mathrm{hr}$, eggs were in the morular stage (Fig. 2C) and subsequently reached in the blastula stage after $3 \mathrm{hr}$ and $30 \mathrm{~min}$ (Fig. 2D). After $4 \mathrm{hr}$, a blastula covered the yolk and the early gastrula stage was begun (Fig. 2E).

The sphere was closed after five hrs of the fertilization and then the embryo was started to form (Fig. 2F). The head part of embryo started to develop after $6 \mathrm{hr}$ and 30 min of the fertilization. After $7 \mathrm{hr}$, optic vesicles were formed in the head of embryo and Kupper's vesicles were found (Fig. 2G).

Auditory vesicles and 13-17 myomeres were formed after $8 \mathrm{hr}$ and $30 \mathrm{~min}$ of the fertilization while Kupper's vesicles were disappeared (Fig. 2H).

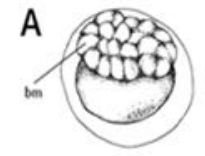

B

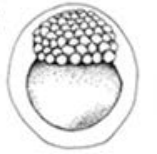

C

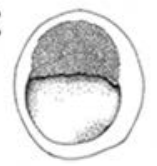

D

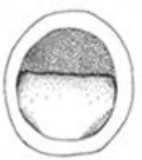

E

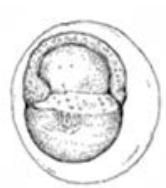

$\mathrm{F}$
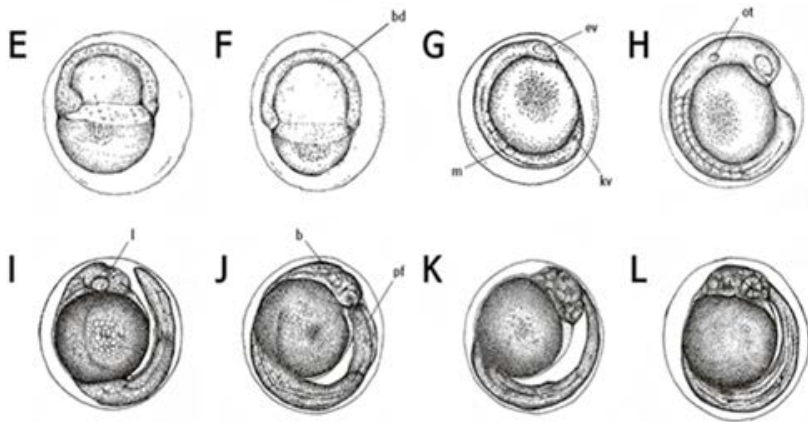

M

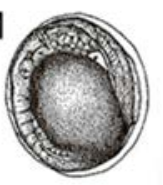

N

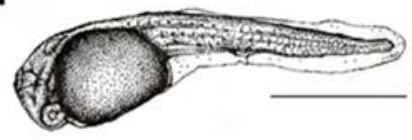

Fig. 2. Embryonic development stages of Hyphessobrycon eques. bm, blastomeres; b, brain; bd, blastoderm; ev, eye vesicle; kv, Kuffer's vesicle; l, lens; m, myotome; ot, otocyst; pf, primordial fin (Shown in Table 1). Scale bar=1.0 mm.

After $11 \mathrm{hr}$ later, there were 20-25 myomeres and the tail was separated (Fig. 2I). Subsequently, after $11 \mathrm{hr}$ and 30 min later, more myomeres (26-28) were found and membrane fins were formed (Fig. 2J). More myomeres, approximately $30-32$, were found after $13 \mathrm{hr}$ and $30 \mathrm{~min}$ later and heart beat was detected while the tail was getting narrow and elongated (Fig. 2K).

The embryo began to move after $14 \mathrm{hr}$ and $30 \mathrm{~min}$ of the fertilization, and blood circulation through the yolk was observed. In this period, myomeres were increased up to 35-38 (Fig. 2L).

After $15 \mathrm{hrs}$ of the fertilization, right before the hatching, the number of heart beating was $70-75$ per min (Fig. 2M). Sixteen $\mathrm{hr}$ later, the upper head was directed at the front end of the egg membrane and started to hatch (Fig. 2N).

1) Prelarvae stage 
Right after their hatching, the whole length of larvae was in between 2.76-3.05 $\mathrm{mm}$ (mean $2.89 \pm 0.16 \mathrm{~mm}$, $n=10)$ the mouth and anus were closed and all fins were membranous. Melanophores were precipitated on the yolk and the numbers of myomeres were $35-38$ in this period (Fig. 3A).

After two days of hatching, the whole length of early larvae was $3.21-3.80 \mathrm{~mm}$ (mean $3.42 \pm 0.38 \mathrm{~mm}$ ) and membranous ventral fin and anal fin started to differentiate. An air bladder was formed on the yolk, and spot-like melanophores were precipitated on the base of eyes and tail (Fig. 3B).

Three days later, the whole length of early larvae was ranging 3.54-3.96 $\mathrm{mm}$ (mean $3.72 \pm 0.24 \mathrm{~mm}$ ) and almost all yolk was absorbed; the mouth and the anus were opened and a fan-shaped membranous pectoral fin was formed. The air bladder was noticeably developed and early diet (rotifers) was consumed to proceed post larvae stage (Fig. 3C).

\section{2) Postlarvae stage}

On day 5 , the whole length of postlarvae was ranging between $3.57-4.20 \mathrm{~mm}$ (mean $3.80 \pm 0.40 \mathrm{~mm}$ ) a membranous ventral and anal fins were separated and five softrays were formed on the caudal fin. The head it self was approximately $69 \%$ of a total body proportion which seems relatively big considering the body size. Melanophores were precipitated on the head and the airbladder and fishes started to consume brine shrimps and assorted feed along with rotifers as their lower jaws were developed (Fig. 3D).

On day 15, the whole length of postlarvae was around $4.44-4.93 \mathrm{~mm}$ (mean $4.78 \pm 0.15 \mathrm{~mm}$ ) the membranous dorsal fin got shorter while the vertebrae and vascular pole were becoming more apparent. The lower jar was getting longer than the upper one and the cannibalism was observed in this period (Fig. 3E).

After 25 days of hatching, the whole length of post larvae

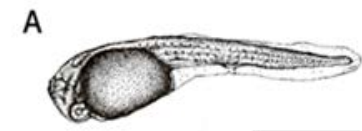

$\mathrm{E}$

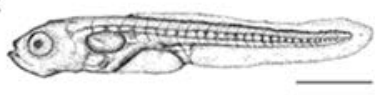

B

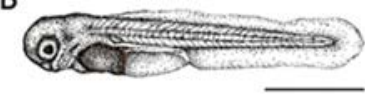

$\mathrm{F}$

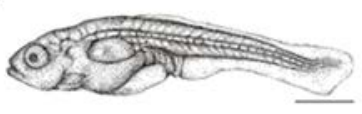

C

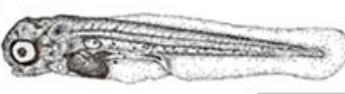

G

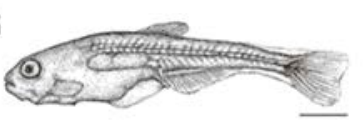

D

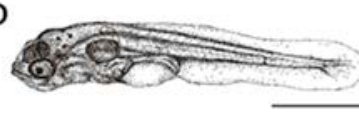

$\mathrm{H}$
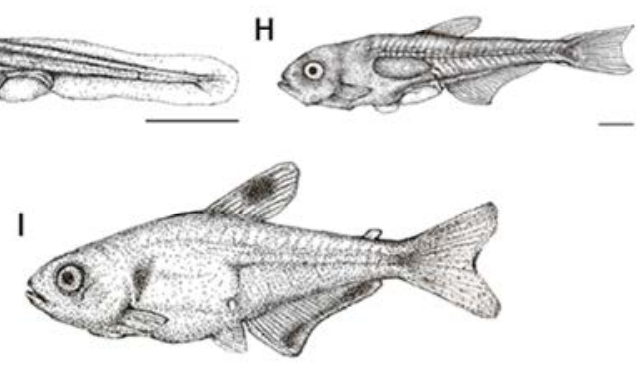

Fig. 3. Morphological development of the larvae and juvenile of Hyphessobrycon eques (Shown in Table 2). Scale bars $=1.0 \mathrm{~mm}$.

was $5.41-6.62 \mathrm{~mm}$ (mean $5.90 \pm 0.72 \mathrm{~mm}$ ) and there were five stems were formed on the pectoral fin; also the end of notochord was bent about $45^{\circ}$. In this period, the head accounted for $62 \%$ of the body and the depth of body was getting longer to take $42 \%$ of the whole body (Fig. 3F).

On day 30 , the whole length of postlarvae was 6.73 $8.06 \mathrm{~mm}$ (mean $7.20 \pm 0.86 \mathrm{~mm}$ ) and the dorsal fin was differentiated to form eight stems there were six stems on the pectoral fin as well. On the anal fin, 17 stems were formed and the fan shaped caudal fin was differentiated to wards the tail. Further, stems were increased up to 18. Melanophores were precipitated on the bottom of the dorsal fin as well as in the middle of the tail (Fig. 3G).

After 40 days of hatching, the whole length of post larvae was $10.2-11.5 \mathrm{~mm}$ (mean $10.2 \pm 1.20 \mathrm{~mm}$ ) and the dorsal fin, anal fin and caudal fin were completely differrentiated. The ventral fin started to be separated to a circular film. There were 10 stems in the dorsal fin while 
Table 2. Meristics and main ontogenetic characters of larvae and juvenile Hyphessobrycon eques reared at mean temperature of $28^{\circ} \mathrm{C}$. Age is given in days post hatching (dph)

\begin{tabular}{|c|c|c|c|c|}
\hline \multirow[b]{2}{*}{ Stage } & \multirow[b]{2}{*}{$\mathrm{dph}$} & $L_{T}^{*}$ & \multirow[b]{2}{*}{ Main morphological and ontogenetic characters } & \multirow[b]{2}{*}{ Fig. 3.} \\
\hline & & $\begin{array}{l}\mathrm{Mean} \pm \mathrm{SD} \\
(\mathrm{mm})\end{array}$ & & \\
\hline \multirow{3}{*}{ Prelarva } & 0 & $2.89 \pm 0.16$ & $\begin{array}{l}35-38 \text { myotomes; all fins formed membrane shape; melanophores appeared on } \\
\text { yolk }\end{array}$ & A \\
\hline & 2 & $3.42 \pm 0.38$ & $\begin{array}{l}\text { Swimbladder formed upper of yolk; beginning of divide pelvic fin with anal fin; } \\
\text { pelvic and anal fin's division begin; cap of melanophores appeared on eyes and } \\
\text { base of tale }\end{array}$ & B \\
\hline & 3 & $3.72 \pm 0.24$ & $\begin{array}{l}\text { Yolk almost fully absorbed; mouth and anal open completely; visible pectoral- } \\
\text { fin; swimbladder develop lagely; eating start (Branchionus rotundiformis) }\end{array}$ & $\mathrm{C}$ \\
\hline \multirow{5}{*}{ Postlarva } & 5 & $3.80 \pm 0.40$ & $\begin{array}{l}\text { Pelvic fin and anal fin divided completely; } 5 \text { soft rays formed in the caudal fin; } \\
\text { head-part elarged; mandible developed lagely; melanophores appeared upper of } \\
\text { swimbladder and head-part }\end{array}$ & $\mathrm{D}$ \\
\hline & 15 & $4.78 \pm 0.15$ & $\begin{array}{l}\text { Dorsal fin was shortened; vertebral column and vascular pole appeared } \\
\text { conspicuously; mandible was lengthened than the upper jaw; cannibalism was } \\
\text { observed }\end{array}$ & $\mathrm{E}$ \\
\hline & 25 & $5.90 \pm 0.72$ & $\begin{array}{l}5 \text { stems formed in the pectoral fin; caudal-fin's divide begin; terminal part of } \\
\text { notochord flexed } 45^{\circ}\end{array}$ & $\mathrm{F}$ \\
\hline & 30 & $7.20 \pm 0.86$ & $\begin{array}{l}8 \text { stems were formed in the dorsal fin; } 6 \text { stems formed in pectoral fin; } 17 \text { stems } \\
\text { formed in the anal fin; caudal fin be homocercal tail }\end{array}$ & G \\
\hline & 40 & $10.2 \pm 1.20$ & $\begin{array}{l}\text { Dorsal, anal, caudal fin were divided completely; } 10 \text { stems formed in dorsal fin; } \\
21 \text { stems formed in anal fin and caudal fin }\end{array}$ & $\mathrm{H}$ \\
\hline Juvenile & 45 & $12.5 \pm 1.60$ & $\begin{array}{l}\text { Adipose fin formed upper of caudal peduncle; } 7 \text { stems formed in pelvic fin; } \\
\text { melanophores appeared on operculum and center of dorsal fin; band of } \\
\text { melanophores appeared on terminal of anal fin }\end{array}$ & I \\
\hline
\end{tabular}

$L_{T}^{*}:$ total length; SD: standard deviation.

stems on the anal fin increased up to 21. Lastly, it was increased up to 21 stems in the caudal fin (Fig. $3 \mathrm{H}$ ).

\section{3) Juvenile stage}

On day 45 , the whole length of fries was $11.9-14.1 \mathrm{~mm}$ (mean $12.5 \pm 1.60 \mathrm{~mm}$ ) melanophores were precipitated on the middle of dorsal fin as well as gill cover while these were precipitated like a horizontal stripe on the end of anal fin. One adipose fin was formed on top of the tail and seven stems were shown on the ventral fin which made them fry a like the irmother fishes. In this period, the head it self was approximately $20 \%$ of a total body proportion and the body depth was shown to be around $29 \%$ as grow, the head and the body depth were relatively getting smaller when compared to the larvae period (Fig. 3I).

\section{DISCUSSION}

As the industry of freshwater aquarium fish grows, it is becoming very common for multiple patterns of aquaculture production for non-native fishes; further, most commercially available ornamental fishes are produced via fish holding 
Spawning Behavior, Egg Development, Larvae and Juvenile Morphology of Hyphessobrycon eques (Pisces: Characidae) Characidae Fishes

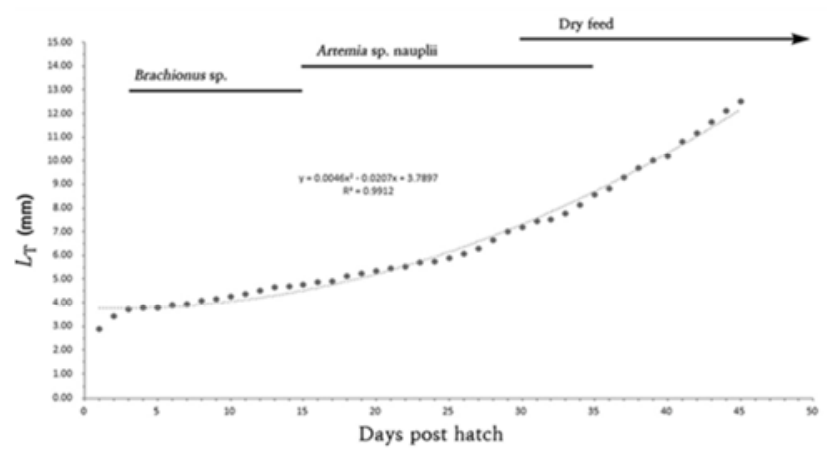

Fig. 4. Larvae growth (in total length, $L_{T}$ ) and feeding schedule during the rearing experiment. Exponential lines and regression coefficients are given $\left(y=0.0046 x^{2}-0.0207 x+3.7897 ; \gamma^{2}=0.9912\right)$ during the rearing experiment.

method. According to the Convention on International Trade in Endangered Species of Wild Fauna and Flora, CITES, direct trade of such species are strictly prohibited due to the strengthened legal regulations, warranting investigations regarding the conservation of species as well as their breeding for sustainable import and export.

Fishes belong to the Characidae family are similar to the Cyprinidae family but they are characterized with pharyngeal teeth in their buccal cavity; in contrast, fishes of the Cyprinidae family have these teeth in the throat (Kim et al., 2005a). When compared the structure of pharyngeal teeth of the Cyprinidae family, fishes such as Cyprinus carpio, Cuprinus carpio nudus, and Carassius carassius are omnivore but close to herbivorous; these fishes are featured with well developed pharyngeal teeth as they chew and swallow food from the bottom (Kim et al., 2005b).

In contrast, small fishes such as Hyphessobrycon eques do not chew foods but just swallow, making them to have degraded pharyngeal teeth but in the buccal cavity. There is one adipose fin on top of tail of Hyphessobrycon eques which is also found in other fishes including Oncorhynchus keta, and Plecoglossus altivelis (Myoung \& Kim, 1993; Kim et al., 2005b). Hyphessobrycon eques is known to not swim for long time in water but rather stay on the bottom in a place where there is no flow speed and then move; this pattern is repeated. It is considered that the adipose fin aids to maintain balance and keep buoyancy in the water while swimming. Fertilized eggs of Hyphessobrycon eques are round shape with red colored yolk.

These are sticky demersal egg without lipid droplets. The size of eggs was ranging $0.91-0.93 \mathrm{~mm}$ TL (mean $0.92 \pm$ $0.01 \mathrm{~mm}$ ) which is bigger than other fishes belong to the same family $0.65 \mathrm{~mm}$ TL of tiger fish, and Hydrocynus vittatus (Steyn et al., 1996) whereas smaller than Brycon gouldingi $1.13 \mathrm{~mm}$ TL (Faustino et al., 2011), and Brycon orthotaenia 1.49-3.09 mm TL (Gomes et al., 2011).

When comparing the time takes for hatching, it took 12 $\mathrm{hr}$ at $28.0 \pm 0.05^{\circ} \mathrm{C}$ for Hyphessobrycon eques whereas 22.5 hr at $28.0 \pm 1{ }^{\circ} \mathrm{C}$ and $13 \mathrm{hrs}$ at $26.4 \pm 1.12^{\circ} \mathrm{C}$ for Tiger fish and B. gouldingi, respectively., Montoya et al. (2010) reported that it takes $28 \mathrm{hr}$ and $20 \mathrm{~min}$ at $21^{\circ} \mathrm{C}$ and $21.5 \mathrm{hr}$ at $24^{\circ} \mathrm{C}$ for Bryconamericus caucanus and B. orthotaenia to hatch, respectively (Montoya et al., 2010) which is not

Table 3. Comparison of egg and larvae characteristics in Characidae fishes

\begin{tabular}{ccccc}
\hline \hline Species & $\begin{array}{c}\text { Egg diameter } \\
(\mathrm{mm})\end{array}$ & $\begin{array}{c}\text { Time of hatching } \\
(\text { water temp. })\end{array}$ & $\begin{array}{c}\text { Hatching } \\
\text { larvae size }(\mathrm{mm})\end{array}$ & Reference \\
\hline Hyphessobrycon eques & $\begin{array}{c}0.92 \pm 0.01 \\
(0.91-0.93)\end{array}$ & $12 \mathrm{hrs}\left(28.0 \pm 0.05^{\circ} \mathrm{C}\right)$ & $2.89 \pm 0.16(2.76-3.05)$ & Present study \\
\hline Hydrocynus vittatus & 0.65 & $22 \mathrm{hrs}\left(28.0 \pm 1^{\circ} \mathrm{C}\right)$ & 2.90 & Steyn et al., 1996 \\
\hline Brycon gouldingi & 1.13 & $13 \mathrm{hrs}\left(26.4 \pm 1.12^{\circ} \mathrm{C}\right)$ & - & Faustino et al., 2011 \\
\hline Brycon orthotaenia & $1.49-3.09$ & $21 \mathrm{hrs} 30 \mathrm{mins}\left(24.0^{\circ} \mathrm{C}\right)$ & $2.87 \pm 0.15$ & Gomes et al., 2011 \\
\hline Bryconamericus caucanus & - & $28 \mathrm{hrs} 20 \mathrm{mins}\left(21.0^{\circ} \mathrm{C}\right)$ & - & Montoya et al., 2010 \\
\hline
\end{tabular}


significantly different with $B$. gouldingi, but faster than tiger fish, B. caucanus, and B. orthotaenia. As shown, fishes in the Characidae family represent slow in development in low water temperature whilst it is accelerated in high water temperature (Byun et al., 2009).

When compared the larvae size right after hatching, the whole length of Hyphessobrycon eques was 2.76-3.05 mm TL (mean $2.89 \pm 0.16 \mathrm{~mm}$ ) which is slightly longer than those of $B$. orthotaenia (mean $2.87 \pm 0.15 \mathrm{~mm}$ ) while shorter than tiger fish (mean $2.90 \mathrm{~mm}$; Table 3).

In general, there are various external variations in regards to the lifestyle of larvae, causing issues on their classification (Hwang et al., 2006). Therefore, morphological development and early development processes are often utilized as preliminary data for not only species identification but also protection of endangered species (Seo et al., 2010). Lately, fishes belong to the Characidae family are significantly decreased in number due to reckless overfishing thus warrants to perform follow-up studies regarding brood stock culture management and ecological studies including their lifestyle and environments.

\section{ACKNOWLEDGEMENT}

This research was supported by grants from the National Fisheries Research and Development Institute (NFRDI) in Korea (RP-2014-AQ-149).

\section{REFERENCES}

Byun SG, Lee SH, Hwang JH, Han KH, Kang KW, Kim JD, Kim YC, Lee BI (2009) Embryonic and larva development of slime flounder, Microstomus achne. Dev Reprod 13:281-289.

Cole BE, Haring M (1999) Spawning and production of the serpae tetra, Hyphessobrycon serpae. Univ of Hawaii Sea Grant Extension Service. Hawaii pp. 2-4.
Faustino F, Nakaghi LS, Neumann E (2011) Brycon gouldingi (Teleostei, Characidae): aspects of the embryonic development in a new fish species with aquaculture potential. Zygote 19:351-363.

Gomes RZ, Sato Y, Rizzo E, Bazzoli N (2011) Early development of Brycon orthotaenia (Pisces: Characidae). Zygote 21:11-20.

Hwang SY, Han KH, Lee WG, Yoon SM, Kim CC, Lee SH, Seo WI, Roh SS (2006) Early life histroy of the Tridentiger obscurus (Pisces, Gobiidae). Dev Reprod 10:47-54.

Kim DH, Deung YK, Lee KJ (2005a) Ultrastructure of the fertilized egg envelope from Hyphessobrycon serpae, Characidae, Teleost. Korean J Elec Micro 35:89-96.

Kim DH, Reu DS, Deung YK (1996) A comparative study on the ultrastructures of the egg envelope in fertilized egg of fishes, Characidae: Three Species. Korean J Elec Micro 26:277-291.

Kim DY, Jung MM (2011) A study on development direction for ornamental fish industry in Korea. J Fish Mar Sci Edu 23:626-641.

Kim DY, Kang JH (2012) Improvement of ornamental fish industry through analysis of recognition and market scale of the ornamental Fish. J Fish Bus Adm 43:89106.

Kim IS, Choi Y, Lee CL, Lee YJ, Kim BJ, Kim JH (2005b) Illustrated Book of Korean Fishes. Kyo Hak Publishing, Seoul, Korea pp. 276-286.

Lee WO (2012) Breeding and maintenance of aquarium fishes. Ministry for Food, Agriculture, Forestry and Fisheries. Fishermen Education: A text book for aquarium fishes manager pp. 57-77.

Montoya A, Arias M, Olivera-Angel M (2010) Embryonic development of Bryconamericus caucanus (Characidae: Tetragonpterinae) under laboratory conditions. Int $\mathbf{J}$ Mor 28:869-872. 
Spawning Behavior, Egg Development, Larvae and Juvenile Morphology of Hyphessobrycon eques (Pisces: Characidae) Characidae Fishes

Myoung JG, Kim YU (1993) Morphological study of Oncorhynchus spp. (Pisces : Salmonidae) in Korea IV. Comparison of morphological characters of chum salmon Oncorhynchus keta, masu salmon, Oncorhynchus masou and rainbow trout Oncorhynchus mykiss. Korean J Ichthyol 5:96-112.

Nakaghi LS, Neumann E, Faustino F, Mendes JM, Braga FM (2013) Moments of induced spawning and embryonic development of Brycon amazonicus (Teleostei, Characidae). Zygote First View Article 22:549-557.

Pan CH, Chien YH, Wang YJ (2011) Antioxidant defence to ammonia stress of characins (Hyphessobrycon eques Steindachner) fed diets supplemented with carotenoids. Aquacult Nutrit 17:258-266.

Rusell FS (1976) The Eggs and Planktonic Stages of British Marine Fishes. Academic Press Inc, London pp. 524.

Seo WI, Yoo DJ, Byun SG, Kim YC, Lee SH, Yeon IH, Yim HS, Lee BI (2010) Spawning behavior and early life history of endangered Cottus hangiongensis. Kor J Fish Aquat Sci 43:46-53.

Steyn GJ, Gagiano CL, Deacon AR, Preez HH (1996)
Notes on the induced reproduction and development of the tigerfish, Hydrocynus vittatus (Characidae), embryos and larvae. Environ Biol Fish 47:387-398.

Tavares I (1997) Serpae Tetras, Aquarist and Pondkeeper. New York, 61:38-40.

Vandewalle P, Germeau G, Besancenet P, Parmentier E, Baras E (2005) Early development of the head skeleton in Brycon moorei (Pisces: Ostariophysi, Characidae). J Fish Biol 66:996-1024.

Weber AA, Arantes FP, Sato Y, Rizzo E, Bazzoli N (2012) Oocyte adhesiveness and embryonic development of Astyanax bimaculatus (Linnaeus, 1758) (Pisces: Characidae). Zygote 21:198-202. 